\title{
The Assessment Practices of Pre-service English Language Teachers' Performance from the University Supervisors' Experiences
}

\author{
Moza Abdullah Al-Malki
}

\begin{abstract}
This pilot study reports on 10 university supervisors' lived experiences about practices used for assessing classroom performance of pre-service English Language (EL) teachers. In Oman, those university supervisors, who came from different nationalities, play a major role in assessing the pre-service teachers when the latter are practicing teaching during their final year of teacher education program. This qualitative driven by interpretive phenomenological study reveals these practices as understood in one institution, called Rustaq-College of Applied Sciences (CAS) in Oman. The study conducts individual semi-structured interviews with those university supervisors. Their understandings of the practices are presented and discussed in relation to pertinent literature about international best assessment practices. The findings have important implications for my PhD study and for further reconsideration about the current assessment practices of the university supervisors in Oman and in any ELT context.
\end{abstract}

Index Terms-Pre-service EL teachers, assessment practices, university supervisors' experiences and interpretive phenomenological approach.

\section{INTRODUCTION}

Pre-service English Language (EL) teachers are required to take school-based teaching practicum in their teacher education program. The school-based teaching practicum enables the pre-service teachers to practice their teaching performance before graduating. Assessing their teaching classroom performance is considered a high-stake as it determines if those pre-service teachers will be qualified and ready to teach or not.

English teacher education programs in Oman have school-based teaching practicum in the final year of their programs. The pre-service EL teachers are assessed through classroom observation which is a common instrument around the world. Stakeholders who are involved in assessing the pre-service teachers are university supervisors and cooperating teachers. The university supervisors are the academic teachers who are teaching the pre-service teachers during their program, while the cooperating teachers are the classroom teachers who teach the class which the preservice teachers are trained and practiced in.

The university supervisors visit schools and assess the pre-service teachers using the designed classroom observation form. In addition to this, the university supervisors are involved in other practices such as feedback

Manuscript received September 2, 2016; revised December 4, 2016.

Moza Abdullah Al-Malki is with the Griffith University, Australia (email: malmalki82@gmail.com). and given grade at the end of the school-based teaching practicum. Investigating how those university supervisors, who are involved in this social phenomenon, experience the practices is the aim of this study. This study will examine the university supervisors' lived experiences of the practices when assessing the classroom performance of the Omani pre-service EL teachers. Investigating how the university supervisors understand their practices is significant for this study. Firstly, the university supervisors play a major a role and weight in assessing the Omani pre-service EL teachers. Secondly, their understanding of the practices is a significant measure of how the Omani pre-service teachers are assessed, which as a consequence will determine the possibility of their readiness to teach. Thus, this pilot study will begin with a review of the literature around the international best assessment practices for the classroom performance of pre-service teachers. Then, the littleresearched of university supervisors' experiences about these practices will be explained. Followed, the literature will conclude with the research question that will guide this study.

\section{LITERATURE REVIEW}

In the recent years, there has been a shift in the field of assessment for new and pre-service teacher. Instead of focusing on input measures such as grade point average, credits taken and content knowledge examinations, the trend is focusing on output measures which are performance assessments, portfolios and observations of teaching practice [1]. During observations of teaching practice, assessors assess the pre-service teacher performance against a set of criteria to determine the degree to which the pre-service teacher performance meets the criteria for teaching. This criterion-reference measure is what recently known as authentic assessment.

In the field of pre-service teacher education around the world, authentic assessment is considered a trustworthy form of assessment that reflects the nature of teacher's work [2], [3]. According to this recent Queensland College of teachers' report [2], authentic assessment is defined as follows,

Authentic assessment requires preservice teachers to deploy combinations of knowledge, skills, and dispositions in their professional life. Authentic assessment makes the core aspects of teaching visible and measurable against a set of agreed standards. Authentic tasks engage preservice teachers in processes that are necessary to act professionally in planning curriculum units for a specific group of students, 
designing episodes of teaching, teaching, and evaluating the effectiveness of their teaching. Authentic assessment, therefore, requires preservice teachers to be explicit about their thinking and decision-making in designing teaching episodes, to reference the sources and rationale for their ideas, and to reflect upon the actual teaching experience and plans for revising and redesigning the teaching episodes. This dissolves the division between theory and practice and creates a system of reflective practice that adds to the professional knowledge of teaching.

The purpose behind such a definition has urged stakeholders of pre-service teacher education programs (such as United States of America and Australia) to create, in addition to the classroom observation criteria, structured or unstructured portfolio assessments (so-called Performance Assessment for California Teacher: PACT and Deakin Authentic Teacher Assessment: ATA) to enable preservice teachers experience an ownership of their role of becoming a reflective practitioner. More importantly, the criteria in the classroom observations are aligned with teaching professional standards as a means for guaranteeing quality and accountability. As a consequence of this and as [2] emphasized that an effective teacher evaluation system should be 'based on professional teaching standards' and 'include multifaceted evidence of teacher practice, student learning, and professional contributions that are considered in an integrated way' (p. 153). Having had an effective teacher evaluation system, these programs have provided a rich evidence of their pre-service teachers' readiness to teach.

The discourse of standards for teaching is as much about enhancing teaching quality as well as providing appropriate professional learning opportunities for teachers throughout their careers [4]. Several studies have demonstrated how professional teacher standards can define good practice and act as powerful vehicles, useful mechanisms and useful reference points for teaching credentials, appraisals and professional development e.g., [5]-[7]. [8] adds to this debate claiming that a set of professional standards can increase teachers' effectiveness and their public credibility.

Many countries around the world have implemented professional standards in their teacher education programs. The Australian Professional Standards for Teachers (APST) were devised by the Australian Institute for Teaching and School Leadership (AITSL) and are a public statement of what constitutes teacher quality (AITSL, 2014). According to the [9], the standards "provide a framework that makes clear the knowledge, practice and professional engagement required across teachers' careers. They present a common understanding and language for discourse between teachers, teacher educators, teacher organisations, professional associations and the public" (p. 2).

In the Middle East, teacher professional standards are also recognized as an important factor for improving quality education. For example, Qatar has called on the service of Australian (Queensland) educators to develop the Qatar National Professional Standards for School Teachers and Leaders (QNPSTSL). QNPSTSL have been implemented as a common reference point to "describe the skills, dispositions and knowledge teachers and school leaders need to know in order to be effective in their profession" [10] (p. 110). Oher countries, both developed and developing, are also implementing teacher professional standards in their teacher education programs as a means of capturing their own vision of what constitutes a quality teacher in their context.

The experience of assessors regarding authentic assessment and standards for teaching is not well-studied. There is paucity of research, in particular, regarding university supervisors' experiences of how pre-service teacher performance assessment is practiced. This dearth of research could be due to firstly that the university supervisors usually do not play a role in the assessment process. For example, In Australia, the pre-service teachers are solely assessed by the supervising teacher who is the class cooperating teacher [11].

Secondly, research examining the university supervisors' roles as assessors is often correlated with the class cooperating teachers' roles. For example, [12] indicated that the university supervisors and the classroom cooperating teachers depend on their professional judgement to decide what is passing or proficient pre-service teacher performance because many observation rating instruments have either a) 'met' or 'not met' or b) four to five levels of performance with no descriptions of what performance look like at these various levels. Moreover, [13] found that the both the university supervisors and the cooperating teachers provided support for the pre-service teachers either on providing feedback of the observed lessons (university supervisor's role) or on cooperating with pre-service teachers of how to plan lesson sequences for the schoolbased teaching practicum (cooperating teacher's role).

This study investigated how the university supervisors experience the assessment practices pertinent to the classroom performance of Omani pre-service English Language teachers during their school-based teaching practicum. In order to answer this question, this pilot study took place in one of the higher education institutions in Oman. This institution which is Rustaq-College of Applied Sciences hosts, in addition to Business and Information Technology programs, an English teacher education program. The following section describes in details an English teacher education program in Rustaq where the study has been conducted, who will be involved in the study, how will I approach the participants and what findings the study reveal in order to understand the participants' experiences regarding the investigated phenomenon.

\section{MYthOLOGY}

\section{A. Rustaq-College of Applied Sciences (Oman)}

Rustaq College of Applied Sciences (RCASs) offers an education program for English language teaching in Oman. It is a governmental college under the umbrella of the ministry of Higher education. The English Education program in RCASs has theoretical courses and practical courses. The practical courses are the courses where the preservice teachers practice teaching in the college and in schools. The ones which are in the college are practicum 1 and practicum 2 and the ones which are in schools are practicum 3 and practicum 4. These latter courses are 
offered in the final year of the program where the preservice teachers go to school twice a week for the two semesters in addition to the courses they take in the college. For example, in the first semester the pre-service teachers have four courses in the college plus practicum 3: twice a week in the school; whereas in the second semester they have three courses in the college plus practicum 4: twice a week in the school. In practicum $3 \& 4$, a pre-service teacher is assessed by two university supervisors during the semester. These two university supervisors swap schools in the second half of the semester so that they can assess different groups of pre-service teachers in a different school.

\section{B. University Supervisors}

The ten participants' university supervisors are qualified to teach English language teachers and have had a supervision experience either in Oman or in other countries. Those university supervisors including their gender, nationalities and supervision experience are indicated in Table I.

TABLE I: THE UNIVERSITY SUPERVISORS' (US) GENDER, NATIONALITY

\begin{tabular}{|l|l|l|l|}
\hline \multicolumn{5}{|l}{ AND SUPERVISION EXPERIENCE } \\
$\begin{array}{l}\text { Supervisor } \\
\text { (Us) }\end{array}$ & Gender & Nationality & $\begin{array}{l}\text { Supervision } \\
\text { experience }\end{array}$ \\
\hline Us\#1 & Male & Omani & Since 2000 \\
\hline Us \#2 & Male & Omani & Since 2014 \\
\hline Us \#3 & Male & Omani & Since 2011 \\
\hline Us \#4 & Male & Iranian & Since 2001 \\
\hline Us \#5 & Female & Iraqi & Since 2013 \\
\hline Us \#6 & Male & Jordanian & Since 2010 \\
\hline Us \#7 & Male & Sudanese & Since 2008 \\
\hline Us \#8 & Male & Sudanese & Since 2011 \\
\hline Us \#9 & Female & Romanian & Since 2012 \\
\hline Us \#10 & Female & South African & Since 2000 \\
\hline
\end{tabular}

\section{Semi-Structured Interviews}

Face to face semi-structured interviews were conducted with the ten university supervisors. The questions were open in order to allow the participants to describe their experience and how they experience it. The targeted questions were concerning the participants' role in the assessment, the positive aspects and construing factors, and their reflection on the whole experience. The interview guideline is provided in Appendix (1).

\section{DATA ANALYSIS}

An interpretive phenomenological approach (IPA) was utilized to analyze the semi-structured interviews as it captures the lived- experience [14]. [14] provided a more authentic step-by-step IPA to follow. These steps are as 1) reading and re-reading the transcripts; 2 ) initial noting of the transcripts; 3) developing emergent themes; 4) searching for connections across the emergent themes and finally 5) moving to the next case or participant. I adopted the steps of data analysis that are recommended by [14] but as suggested have also allowed some flexibility in the process. I read the 10 transcripts several times and summarize each one to have an understanding of that particular participant's experience, and then I moved to the second one and did the same and ext.
After that, I read the summary of each one and looked for connections among the participants' experiences as summarized and when needed I returned to the original transcripts. So, it is an iterative process. The following section presents the findings of the analysis and the discussions of these findings.

\section{FINDINGS AND DISCUSSIONS}

The analysis of the 10 university supervisors' experiences regarding the practices used to assess the classroom performance of Omani pre-service EL teachers during the school-based teaching practicum reveal four main practices: undefined criteria per a lesson; providing feedback and gauging performance; lack of cooperation with the cooperating teacher and agency of pre-service teachers. These practices will be presented and discussed in the following paragraphs.

\section{A. Undefined Criteria per a Lesson}

The university supervisors used the criteria given by the RCASs to evaluate the classroom performance of the preservice teachers. the Us\#1 said, "we use checklist to evaluate our student performance trainee at school and that checklist consists of 20 items which has different categories: such as personality, about language, about instruction and class management. However, each supervisor has his/her own way of assessing an observed lesson. The Us\# 2 described his way of assessing the observed lesson during the actual assessment process saying,

"Actually during the class I write everything student trainees do and after the class I can easily go step by step but normally I divided them into two things: what do you like about that class and suggestions for improvement and I always start with the good things regarding that class and even with these good points I start from the beginning what he did from the beginning till he finished for example the warm-up activity task, what are the good things about this task and then the first task and the second task and then move again to the suggestions for improvement, for example in the warm-up how can we improve it? how can I make it better? And if there is any grammatical mistakes or vocabulary mistakes spelling I raise them wherever we reach a stage of a particular task a student trainee did".

While the Us\#2 observed everything about the class from the warm-up activity and until the last task of the lesson, the Us\#4 focused more on the instruction and language. He justified his emphasis on these two criteria as, "teachers have to be very clear about the instruction, monitoring while they are doing the activity, and be a facilitator in the class. The instruction is very important for the students to learn". And regarding language, he commented, "those who are good command in language are successful as they are confident in presenting the language and they become good teacher because they will enter class with confidence."

The reason behind the undefined criteria on the observed lesson between the university supervisors is as Us\#9 mentioned because 'the criteria more often are subjective'. So when asked her about how can it be improved, she suggested, "standardized benchmark". Similarly, the majority of the University supervisors are hoping for further 
defined criteria. The Us\#2 suggested that, "there should be a form or a benchmark where all university supervisors should refer to describe which degree student trainees have achieved in a particular aspect". Furthermore, the Us 4\# suggested that the university supervisor should inform preservice teachers on "what is he looking at, which part he is focusing on and which part he is not focusing on" before the lesson is observed. Involving pre-service in the assessment regarding the basic knowledge of assessment, defining what to assess, deciding on tools, and developing criteria strengthen the construct validity of assessment as proposed by [15].

\section{B. Providing Feedback and Gauging Performance}

The university supervisors have a dual-role: the first role is to provide feedback after the classroom observation. They all deem feedback as a significant practice through which the university supervisors transfer their knowledge to the pre-service teacher and as a consequence it improves preservice teacher teaching performance. The Us\#7 said, 'feedback is a feedback if there is an action'. So, after the classroom observation, he provided the pre-service teachers with a descriptive feedback and then a written feedback and next time as he said, "check and follow if student trainees reflect and if there is an action upon it". Similarly, the Us\#10 provided the pre-service teachers with oral feedback and next visit as she said, "see any development and If they [pre-service teacher] listen to my feedback". This finding aligns with [16] and [17] who believed that feedback strategies both affective and cognitive focus on closing the gaps in student performance. Concurrent with the first role, the university supervisors are grading and gauging the preservice teacher performance. The school-based teaching practicum in RCASs is considered a course with a mount of credit hours. Despite this fact, the university supervisors are against the practice of grading performance. The Us \#10 said one of the constraining factors of the assessment system is the "notion of grade" and/or "grade does not reflect the teaching capability of students trainees". Similarly, the Us\#5 suggested that the pre-service teacher performance "not to be graded either you have done or not done which is satisfactory or non-satisfactory". Likewise, the Us\#2 proposed "finding clear descriptions of all degree of performance" and the Us\#9 echoed what the Us\#5 and the Us\#2 suggested and added,

"If the system is set up in a way that does not allow for much improvement then assessment is just reduced to just a grade at the end of the semester when it should really reflect the improvement of students trainees overtime".

The concern of the university supervisors regarding the graded system resonate with the old traditional input measures whereas the new shift as indicated in the abovementioned literature is focusing on the output measures through which the pre-service teachers can demonstrate their professional knowledge and practice and this is what teaching professional standards aim for.

\section{Lack of Cooperation}

The university supervisors admitted of not having cooperation with the classroom cooperating teachers who are also responsible for assessing the classroom performance of pre-service teachers. The Us\#3clarified the lack of cooperation saying,

There is no communication the only communication is between me and the senior teacher [a teacher responsible of class cooperating teachers]. Our cooperation is setting timetable with students trainees so I have to observe from periods 1-6 and I don't touch the way of assessing students trainees. I have my own way and they have their own way. Mostly the coordination is regarding an administrative issue. Also, it depends on schools, 95\% I communicate with the senior teacher not the cooperating teacher. Moreover, the Us\# did not have any cooperation with the cooperating teachers and had no idea about the criteria the cooperating teachers are using to assess the pre-service teachers. However, she admitted that the cooperating teachers "are familiar with the level of students and their feedback is valuable". The Us\#10 attributed the lack of cooperation to the large number of pre-service teachers they have to observe when they visit schools. So, she only approached them when there is a major problem related to school issues or classroom performance of pre-service teachers. However, [15] confirmed that all stakeholders involved in the schoolbased teaching practicum are crucial to ensure high quality assessment of the practicum which is conducive to "quality of teacher education" (p. 284). In another word, cooperation and communication between all stakeholders empower the assessment of the school-based teaching practicum.

\section{Agency of Pre-service Teachers}

A final practice that is revealed through the university supervisors" experiences is the agency of pre-service teachers in the assessment process. The pre-service teachers are allowed to have a voice in an oral feedback where both parties discuss the observed lesson and accordingly the preservice teachers can defend their performance, seek clarification for any misinterpretation. The Us\#4 reported on the agency of the pre-service teachers saying, "I usually wait for the self-reflection form to train them to evaluate themselves". Similarly, the Us\#8 elaborated in the selfreflection form which the pre-service teachers are involved in after presenting their lessons. He clarified that the preservice teachers "reflect on their performance indicating where the strong points are and think about weakness and usually deal with them in the reflection and how to solve such issue in the future". [18] Study indicated that preservice teachers reflected on their teaching in profound ways when they were afforded opportunities to engage in dialogues with their assessors. Moreover, the Us\#1 added that the pre-service teachers are encouraged to evaluate each other, a peer-observation, which is, as he described, "a good training". Peer-observation is well-research of its effectiveness in improving the quality of teaching see [19][21] as the peers assist each other in improving their teaching practices.

\section{CONCLUSION AND IMPLICATION}

The purpose of this study is to investigate the university supervisors' experiences regarding the assessment practices of the classroom performance of pre-service English Language teachers. They experienced undefined criteria when assessing the classroom performance of pre-service 
teachers. However, having defined criteria of what to assess assists university supervisors and pre-service teachers to have a focus and as a consequence improve the classroom performance, which is the aim of the school-based teaching practicum. Also, the university supervisors experienced providing feedback to improve the pre-service teacher performance and at the same time they experienced grading that performance which some of them found it a constraining factor. Therefore, they suggested a benchmark or standards which have descriptions of what the performance should look like with no grade in it. Moreover, they experienced lack of cooperation with the cooperating teachers although research emphasized having such cooperation empowers the assessment of school-based teaching practicum. Finally, the university supervisors experienced having agency for pre-service teachers through self-reflection and through peer-observation to enhance their classroom performance.

Thus, this study is significant. Firstly, it has added to the body of knowledge on the little-studied research about the university supervisors' experiences in the ELT context. Secondly, the findings of this study are significant as they have practical application or implications for future research The first practical application for university supervisors is to define what to assess and have a pre-discussion with the preservice teachers so that both of them have a clear purpose of what to achieve. The second practical application is to strength the relationship with the cooperating teachers as their feedback is valuable and can empower the assessment and enhance the pre-service teachers' classroom performance. The third practical application is to reconsider the grading system and emphasize on the value of feedback. This practical application implies for future research which investigate the effectiveness of grading system on the preservice teacher classroom performance.

\section{APPENDIX}

Interview guideline

1) Can you tell me your supervision experience?

2) Can you tell your experience regarding the assessment process?

3) Can you tell your cooperation with school and the cooperating teacher?

4) Can you tell me the role of pre-service teachers in the assessment process?

5) Can you tell me the feedback you provide after the classroom observation? And what kind of feedback do you provide?

6) Can you tell how might the assessment be improved?

\section{REFERENCES}

[1] S. Caughlan and H. Jiang, "Observation and teacher quality critical analysis of observational instruments in preservice teacher performance assessment," Journal of Teacher Education, vol. 65, no. 5, pp. 375-388, 2014
[2] L. Darling-Hammond, P. Newton, and C. Wei, "Developing and assessing beginning teacher effectiveness: The potential of performance assessments," Educational Assessment, Evaluation and Accountability, vol. 25, no. 3, pp. 179-204, 2013.

[3] An investigation of best practice in evidence-based assessment within preservice teacher education programs and other professions, report of research commissioned by the Queensland College of Teacgers. (2012). [Online]. Available: http://qct.edu.au/pdf/BestPpracticeEvidenceBasedAsessmentPreservic eReacherEdPrograms.PDF

[4] P. Mahony and I. Hextall, Reconstructing Teaching: Standards, Performance, and Accountability, Hoboken: Routledge, 2000.

[5] L. Darling-Hammond, B. Berry, and A. Thoreson, "Does teacher certification matter?" Evaluating the Evidence, vol. 23, pp. 57-77, Thousand Oaks, CA: Sage Publications, 2001.

[6] P. Flowers and R. Hancock, "An interview protocol and scoring rubric for evaluating teacher performance," Assessment in Education: Principles, Policy \& Practice, vol. 10, no. 2, pp. 161-168, 2003.

[7] D. Mayer, J. Mitchell, D. Macdonald, and R. Bell, "Professional standards for teachers: A case study of professional learning," AsiaPacific Journal of Teacher Education, vol. 33, no. 2, pp. 159-179, 2005 .

[8] A. Hargreaves, "Four ages of professionalism and professional learning," Teachers and Teaching, vol. 6, no. 2, pp. 151-182, 2000.

[9] AITSL. (2014). Australian Institute for Teaching and School Leadership. [Online]. Available: http://www.aitsl.edu.au/australianprofessional-standards-for-teachers

[10] M. H. Romanowski, "A Habermasian analysis of Qatar's national teacher professional standards," International Journal of Education, 2014.

[11] A. C. Allard, D. Mayer, and J. Moss, "Authentically assessing graduate teaching: Outside and beyond neo-liberal constructs," The Australian Educational Researcher, vol. 41, no. 4, pp. 425-443, 2014.

[12] R. C. Wei and R. L. Pecheone, "Assessment for learning in preservice teacher education: Performance-based assessments," Teacher Assessment and the Quest for Teacher Quality, pp. 69-132, 2010.

[13] R. R. Chung, "Beyond assessment: Performance assessments in teacher education," Teacher Education Quarterly, vol. 35, no. 1, pp. 7-28, 2008.

[14] J. A. Smith, P. Flowers, and M. Larkin, Interpretative Phenomenological Analysis: Theory, Method, and Research, Los Angeles, CA: Sage, 2013.

[15] K. Smith, "Empowering school-and university-based teacher educators as assessors: A school-university cooperation," Educational Research and Evaluation, vol. 13, no. 3, pp. 279-293, 2007.

[16] J. Hattie, Visible Learning: A Synthesis of Over 800 Meta-Analyses Relating to Achievement, New York; London: Routledge, 2013.

[17] D. R. Sadler, "Ah!... So that's 'quality'," in Assessment: Case Studies, Experience and Practice from Higher Education, Schwartz, P. and Webb, G. Eds., pp. 130-136, London: Kogan Page, 2002.

[18] P. Rennert-Ariev, "A theoretical model for the authentic assessment of teaching," Practical Assessment Research \& Evaluation, vol. 10, no. 2, pp. 151-163, 2005

[19] R. R. Day, "Peer observation and reflection in the ELT practicum," Dil ve Edebiyat Egitimi Dergisi, vol. 2, no. 8, p. 1, 2013.

[20] G. D. Hendry and G. R. Oliver, "Seeing is believing: The benefits of peer observation," Journal of University Teaching and Learning Practice, vol. 9, no. 1, p. 7, 2012.

[21] D. McGrath and S. Monsen, A Discussion Paper Prepared for the Peer Observation of Teaching Colloquium, Institute for Teaching and Learning Innovation, 2015

Moza Abdullah Al-Malki was born on October 28th, 1982 in Muscat, Oman. She is a lecturer at Rustaq-College of Applied Science (RCAS) since 2007. She has completed a bachelor in education degree from Sultan Qaboos University, Oman, a master degree in applied linguistics, from University of Queensland, Australia and currently undertaking the $\mathrm{PhD}$ in School of Education and Professional Studies, Griffith University, Australia. 